\title{
Does Credit Rating Matter on Risk Disclosure?
}

\author{
BUNYAMIN BUNYAMIN ${ }^{1}$, DWI NITA ARYANI ${ }^{2}$, IMAMA ZUCHROH ${ }^{3}$, SUKO RAHARJO 4 \\ ${ }^{1}$ Management Study Programs, STIE MALANGKUCECWARA, INDONESIA, E-mail: benz@stie-mce.ac.id \\ ${ }^{2}$ Management Study Programs, STIE MALANGKUCECWARA, INDONESIA, E-mail: dwinita@stie-mce.ac.id \\ ${ }^{3}$ Management Study Programs, STIE MALANGKUCECWARA, INDONESIA, E-mail: imama_zuchroh@yahoo.com \\ ${ }^{4}$ Management Study Programs, STIE MALANGKUCECWARA, INDONESIA, E-mail: zukoraharjo@hotmail.com
}

\begin{abstract}
This research investigates the partial and simultaneous the influence of leverage, profitability, credit rating on risk disclosure. This research involved thirteen public banks on the Indonesia Stock Exchange in 2014-2019. Risk disclosure is measured by counting risk keywords in each annual report. The panel data analysis was employed to test the effect of Leverage (X1), Profitability (X2), and Credit Rating (X3) on Risk Disclosure (Y). Hypotheses testing used multiple linear regression or OLS (Ordinary Least Square). The finding indicates that Leverage and Credit Rating do not influence Risk Disclosure. Leverage, Profitability, and Credit Rating simultaneously influence Risk Disclosure.
\end{abstract}

Keywords: Credit rating; Leverage; Profitability; Risk disclosure.

JEL Classification: H80, H89, G32 


\title{
¿Importa la Calificación Crediticia en la Divulgación del Riesgo?
}

\author{
BUNYAMIN BUNYAMIN ${ }^{1}$, DWI NITA ARYANI ${ }^{2}$, IMAMA ZUCHROH ${ }^{3}$, SUKO RAHARJO ${ }^{4}$ \\ ${ }^{1}$ Management Study Programs, STIE MALANGKUCECWARA, INDONESIA, E-mail: benz@stie-mce.ac.id \\ ${ }^{2}$ Management Study Programs, STIE MALANGKUCECWARA, INDONESIA, E-mail: dwinita@stie-mce.ac.id \\ ${ }^{3}$ Management Study Programs, STIE MALANGKUCECWARA, INDONESIA, E-mail: imama_zuchroh@yahoo.com \\ ${ }^{4}$ Management Study Programs, STIE MALANGKUCECWARA, INDONESIA, E-mail: zukoraharjo@hotmail.com
}

\begin{abstract}
RESUMEN
Este estudio investiga la influencia parcial y simultánea del apalancamiento, la rentabilidad y la calificación crediticia en la divulgación del riesgo. En esta investigación participaron trece bancos públicos de la Bolsa de Indonesia en 2014-2019. La divulgación del riesgo se mide contando las palabras clave de riesgo en cada informe anual. El análisis de datos de panel se empleó para probar el efecto del apalancamiento (X1), la rentabilidad (X2) y la calificación crediticia (X3) en la divulgación de riesgos (Y). En la comprobación de las hipótesis se utilizó la regresión lineal múltiple o MCO (mínimos cuadrados ordinarios). Los resultados indican que el apalancamiento y la calificación crediticia no influyen en la divulgación del riesgo. El apalancamiento, la rentabilidad y la calificación crediticia influyen simultáneamente en la divulgación del riesgo.
\end{abstract}

Palabras clave: Calificación crediticia; Apalancamiento; Rentabilidad; Divulgación de riesgos.

Clasificación JEL: H80, H89, G32

Recibido: 08 de Junio de 2021

Aceptado: 01 de Octubre de 2021 


\section{Introduction}

All companies, especially publicly-owned banks possess a responsibility to disclose truthfully their condition by issuing their financial reports annually. The information will be used by stakeholders such as investors and creditors for making important decisions. Banks listed on the Indonesia Stock Exchange as public companies are compelled to fulfill their stakeholders' needs of relevant information about the statements and reports. The reports provide their accountability based on previous and future activities as the banks' responsibility to the stakeholders.

Because numerical accounting numbers in reports or reports can cause misunderstandings, Banks must provide a more detailed explanation. The obligation to disclose information for Banks has been regulated issued by the Financial Services Authority concerning the Implementation of Good Corporate Governance for Commercial Banks as stated in number 55/POJK.03/2016. This mandates all banks to report their performance transparently for stakeholders' interest security purposes.

Elbannan \& Elbannan (2015) asserted that risk disclosures are any quantitative or qualitative information regarding unfavorable conditions and unpredictable circumstances reported in the annual reports. Banks are obligated to disclose their risks due to the information is crucial for for stakeholders such as investors, creditors, and regulators as they use the information to monitor managers, making regulations to maintain financial stability and market discipline (Elghaffar, Abotalib, \& Khalil, 2019). It is beneficial to help stakeholders to gain valuable information for making decision and to minimize risks and uncertainty (Abraham and Cox, 2007); Berreta \& Bozzolan; Linsley and Shrives, 2006).

Jensen and Meckling (1976) proposed agency theory featuring agency relationships, where shareholders (principal) mandate managers (agent) to manage their company. The agent is chosen by the principal to uphold the responsibility and report company management as well as business activities. Stakeholders need company information to prevent and minimalize misconceptions and other unintended occurrences between internal and external parties (Watts \& Zimmerman, 1983).

In addition to the agency theory, stakeholder theory supports the dynamic and complex relationship between companies and stakeholders in which managers bear a responsibility to disclose the current state of the companies. Stakeholders require relevant information for a comprehensive understanding of company risks (Linsley \& Shrives, 2005). Additionally, the signaling theory supports the agency and stakeholder theories. It states that company information is a signal for decision-making as managements provide investors with indicators of how they assess company prospects.

To attract more investors, companies should disclose more transparent financial statements (Ross, 1979). The information within the annual report covers more aspects of company policies, reasons for decision making, and future business plans, thus giving creditors and investors more signals to predict future company prospects and make better decisions. Junaeni (2020) added that knowledge and risks have positive impacts on investment consideration. This highlights that comprehensive information is beneficial before investors make decisions.

Due to substantial risks banks should carry, the Bank of Indonesia issued some regulations on bank liabilities to manage their risks. According to Bank Indonesia Regulation Number 5/8/PBI/2003 and the attached Bank Indonesia Circular Letter Number 5/21/DPNP/2003, banks are obligated to implement effective risk management. It should cover at least: active supervision from the board of directors; availability of policies, procedures, and determination of risk limits; appropriate process for identifying, measuring, monitoring, and controlling risk, included managing an integrated risk management information system; and have a comprehensive system for internal control.

Leverage is the company's policy to find sources of funds from debt along with expenses or fixed costs that must be paid. The company's decision to use debt in investing can affect companies in disclosing their risk, as expressed in agency theory. Jensen and Meckling (1976) explained that companies with high leverage face higher risks and will provide more transparent information. Aryani 
and Hussainey (2017) affirmed that there is a significant negative effect of debt ratio on risk disclosure. This is inconsistent with Al-Shammari (2014), Linsley and Shrives (2006) contending that leverage does not significantly influence risk disclosure.

Profitability is a company's capability to generate profits at a certain level of sales, assets, and equity. Companies with high risk provide high returns. Therefore, as the signaling theory mentions, companies with high profitability send good signals by giving more transparent information in their annual reports to assert that the companies have excellent risk management. The higher the profits, the more transparently the companies report their current state (Elshandidy, Ian Fraser, and Khaled Hussainey (2013), and the more detailed the reports (Rahmani, Maksum, Fachrudin, and Silalahi (2020). Hence, profitability has a positive correlation with risk disclosure (Mousa, 2014). However, other research underlined that profitability does not affect risk disclosure (Aljifri et al., 2014; AlShammari. 2014), and profitability and risk disclosure have a negative association (Klaus. 2005).

Credit rating is "forward-looking opinions about the ability and willingness of debt issuers, like corporations or governments to meet their financial obligations on time and in full"' (Spglobal, 2020). It refers to a company's or country's credit risk assessment based on its financial history, current assets, and liabilities. Credit rating is crucial in market can help between companies and stakeholders. Credit Rating plays a key role in monetary markets in minimising asymmetry information by serving to cut back the informative spatiality between lenders and investors, on one side, and issuers on the opposite side. Changes in credit rating are followed by disclosure level changes within a company (Basu et al., 2018). Bonsall and Miller (2017) suggested that the higher the rating, the more thorough the disclosed information is. Yet, Gillette, Samuels, and Zhou (2020) argued that when companies have a high credit rating, the investors' demand for information disclosure becomes lower. However, Basu and Naughton (2018) found a negative correlation between credit rating and voluntary disclosure.

Condition of economics may disturb companies' performance. As in the figure 1 shown that since 2010, Indonesia's economic growth tended to decrease. However, during the period 2014-2019 had a fairly stable and sloping growth. Unfortunately, in year 2020, economic growth has fallen dramatically. The relatively stable conditions in 2014-2019 might encourage steadily banking performance hence this circumstance supports a good credit rating. Therefore, the period in those interval years becomes the basis for data collection in this study, consequently year 2020 was excluded.

Based on the explanation above, this study purports to measure risk disclosure level in Indonesia listed banks. It also investigates determinants of risk disclosure namely leverage, profitability and Credit Rating during the period 2014-2019.

Figure 1 Indonesia Economic Growth

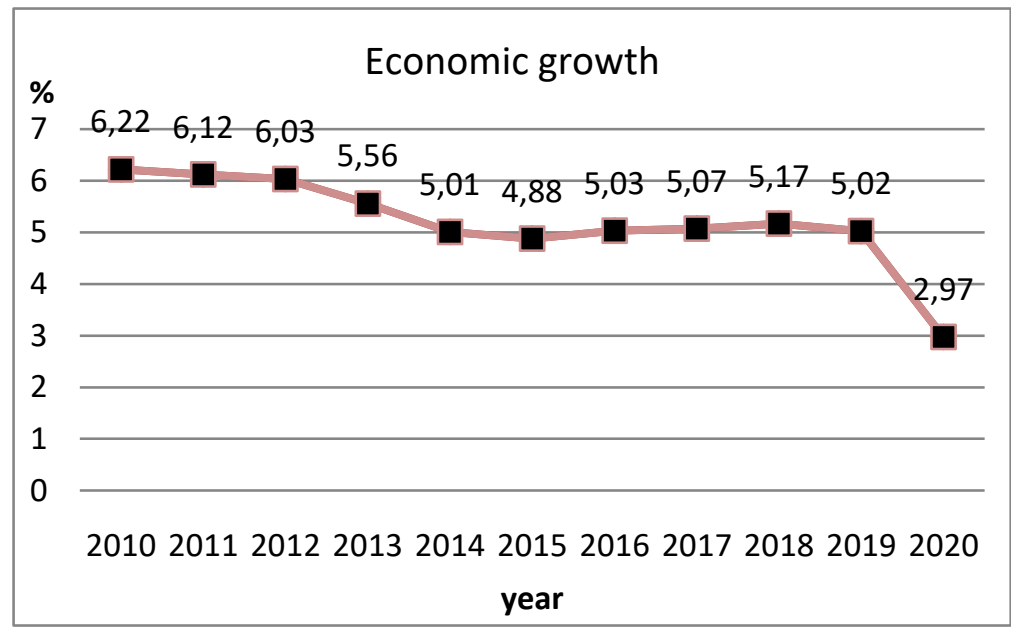




\subsection{Hypothesis development}

The research gaps above become our basis to analyse the effect of leverage, profitability, credit rating on risk disclosure in Indonesian banks. Therefore, this paper suggests hypotheses as follows:

Theory of agency conveys that company which has a progressive leverage ratio will more transparent in reporting information in order to convincing stakeholders. Bank with high level of leverage, the greater high risk and agency cost. Jensen and Meckling (1976) asserted that higher agency costs will be borne if company uses a high debt to finance its operations. In addition, companies which have high leverage need a high supervision that can be done by publishing annual report in more transparent. Rajab and Handley-Schachler (2009); Elzahar and Hussainey (2012) mentioned that leverage does not have an impact on risk disclosure, however Aryani and Hussainey (2017) attested that leverage and risk disclosure has a negative correlation. Meanwhile a correlation between disclosure and leverage with positive direction is found by Alkurdi, Hussainey, Tahat, and Aladwan (2019); Naser, Al-Khatib, and Karbhari (2002). Hence, the first hypothesis is:

$\mathrm{H} 1$ : There is a correlation between leverage and risk disclosure.

Signaling theory reveals that firms which have capability to generate earnings will be more open to reveal risks to stakeholders. Organizations with high profitability will deliver transparent signals to reveal their outstanding performance to investors. Alkurdi et al. (2019); Elshandidy et.al (2013) asserted there is a positive association between profitability and disclosure level. Nevertheless, Soebyakto, Mukhtaruddin, Relasari, and Sinulingga (2018) mentioned that correlation between profitability and disclosure cannot be proven. Therefore, the following hypothesis will be tested:

$\mathrm{H} 2$ : There is a correlation between profitability and risk disclosure.

Basu and Naughton (2018) exhibited that corporate credit rating has correlation with voluntary disclosure. Corroborating with previous study, companies that have low ratings, need more detailed quality information as mentioned by Chi and Flynn (2021). By contrast Gillette, Samuels, and Zhou (2020) explained that stakeholder do not need information in more detail when company has a high credit rating. The following hypothesis is designed:

H3: There is a correlation between credit rating and risk disclosure. In light of the above explanation, thereby we suggested the final hypothesis as follows:

H4: Leverage, profitability, and credit rating simultaneously affect risk disclosure.

\section{Methodology}

A quantitative research approach is conducted in this study. The population was 45 banks listed on the Indonesia Stock Exchange. Purposive sampling is employed to select the sample with two criteria first, banks have published their annual report during the research period in 2014-2019; second, they possess a credit rating from Pefindo (the first Indonesian rating agency established in 1993). After selecting banks which are fit with the criteria, we have gathered 16 banks. For counting the extent of risk keywords processed by QSR-N6 software, all annual reports must be converted into texts. However, three banks must be removed since their annual reports failed to be converted into texts namely Bank Tabungan Negara, CIMB Niaga Bank, and Mayapada International Bank. Finally, the rest of 13 selected banks as the sample are Capital Indonesia Bank (BACA), Bukopin Bank (BBKP), Bank Rakyat Indonesia (BBRI), Danamon Indonesia Bank (BDMN), Bank Pembangunan Daerah Jawa Barat (BJBR), Mandiri Bank (BMRI), Maybank Indonesia Bank (BNII), Permata Bank (BNLI), Victoria Internasional Bank (BVIC), OCBC NISP Bank (NISP), Panin Bank (PNBN), Panin Dubai Syariah Bank (PNBS), and Woori Saudara Indonesia Bank (SDRA).

The independent variables are Leverage (X1) measured by Debt to Total Asset Ratio (DAR), profitability is calculated by Return on Assets (ROA) (X2), and credit rating (X3) that scored 1 (selective default) to 8 (superior) (see Table 1). 
Table 1 Credit Rating

\begin{tabular}{lll}
\hline Rating & Definition & Score \\
\hline idAAA & Superior & 8 \\
\hline idAA+ & Very Strong & 7 \\
\hline idAA & Very Strong & 7 \\
\hline idAA- & Very Strong & 7 \\
\hline idA+ & Strong & 6 \\
\hline idA & Strong & 6 \\
\hline idA- & Strong & 6 \\
\hline idBBB+ & Adequate & 5 \\
\hline idBBB & Adequate & 5 \\
\hline idBBB- & Adequate & 5 \\
\hline idBB+ & Somewhat Weak & 4 \\
\hline idBB & Somewhat Weak & 4 \\
\hline idBB- & Somewhat Weak & 4 \\
\hline idB+ & Weak & 3 \\
\hline diB & Weak & 3 \\
\hline idB- & Weak & 3 \\
\hline idCCC & Vulnerable & 2 \\
\hline idSD & Selective Default & 1 \\
\hline Source: Pefindo. 2020 & & \\
\hline
\end{tabular}

The dependent variable in this study is Risk disclosure $(\mathrm{Y})$ which is measured by calculating the number of risk keywords in the annual reports divided by the number of sentences within. To counting the risk keywords in the annual reports, this study used the QSR Nudist 6.0 software. Elshandidy, Fraser, and Hussainey (2013) proposed risk keywords for measuring risk disclosure namely: "risk*, loss*, decline (declined), decrease (decreased), less, low*, fail (failure), threat, verse (versed, reverse, reversed), viable, against, catastrophe (catastrophic), shortage, unable, challenge (challenges), uncertain (uncertainty, uncertainties), gain (gains), chance (chances), increase (increased), peak (peaked), fluctuate*, differ*, diversify*, probable*, and significant*" for indicating risk disclosure. In addition, Kravet and Muslu (2013: 1094) suggested some risk words consist of can/cannot, could, may, might, risk*, uncertain*, likely to, subject to, potential*, vary*/varies, depend*, expos*, fluctuat*, possibl*, susceptible, affect, influenc*, and hedg*".

Since the keywords are in English and the banks' annual report were delivered in Indonesian language, Aryani and Hussainey (2017) suggested the risk keywords Indonesian translation. They are "aktif, akibat, ancaman, berbeda, dapat, mampu, tidak bisa, tidak dapat, boleh, kemungkinan, risiko, kerugian, potensi, berkurang, kekurangan, kurang, mengurangi, bermasalah, berubah, dampak, fluktuasi, gangguan, menambah, kenaikan, kesempatan, mendapatkan, keuntungan, mencapai, perolehan, lindung nilai, masalah, melanggar, mempengaruhi, meningkat, meningkatkan, menurun, turun, penting, tertinggi, signifikan, tidak stabil".

We pooled our cross-section and time series data. The estimated regression coefficient by performing pooled Ordinary Least Square (OLS) is conducted to test the panel data. Multiple regression analysis and hypothesis testing were carried out through simultaneous and partial tests by using SPSS. Simultaneous Test ( $F$ test) is used to determine whether DAR, ROA, and Credit Rating have a joint effect on Risk Disclosure. This partial test is used to determine the effect of independent and dependent variables partially with the $t$ value on significance level of $5 \%$. 


\section{Results and Discussion}

The statistical data presented in Table 2 and variables data are documented in Table 3 and Table 4. The lowest DAR is 0.73 (73\%) by Panin TBK Bank (PNBN) in 2017, and the highest leverage is 0.97 (97\%) by Panin Dubai Syariah Tbk Bank in 2017. The lowest ROA ratio is $-10.77 \%$ owned by Panin Dubai Syariah Tbk Bank in 2017, and the highest ROA of $4.90 \%$ achieved by Permata Tbk Bank in 2016. The lowest credit rating score (5) generated by Capital Indonesia Bank (BACA) since 2014 to 2019 and Bukopin Bank Tbk in 2018, meanwhile the highest credit rating value (8) have been gained by Bank Rakyat Indonesia Tbk (BBRI), Danamon Indonesia Tbk Bank (BDMN), Mandiri Tbk Bank (BMRI), Maybank Indonesia Bank Tbk (BNII), Permata Tbk Bank (BNLI), OCBC NISP Bank (NISP) and Woori Saudara Indonesia 1906 Tbk Bank (SDRA).

Table 2 Statistic Data of $X 1, X 2, X 3$, and $Y$

\begin{tabular}{lcccc}
\hline & Leverage_X1 & ROA_X2 & Credit Rating_X3 & Risk Disclosure_Y \\
\hline Valid & 78 & 78 & 78 & 78 \\
Missing & 0 & 0 & 0 & 0 \\
Mean & .8517 & 1.6217 & 7.0769 & 0.1320 \\
St. & .04636 & 1.7825 & 1.6217 & 0.08393 \\
Deviation & & & & 0.01 \\
Minimum & .73 & -10.77 & 5.00 & 0.31 \\
Maximum & .97 & 4.90 & 8.00 & \\
\hline
\end{tabular}

Table 2 exhibits that among the 78 data, the lowest risk disclosure of $1 \%$ owned by Bank Pembangunan Daerah Jawa Barat Tbk (BJBR) in 2014 and 2015 while the maximum score (31\%) achieved by Bank Capital Indonesia (BACA) in 2014. Table 3 and 4 presented that average of leverage during year 2014-2019 tended to decrease as well as risk disclosure. The average of credit rating was leveled off in level 7 (very strong), meanwhile ROA was fluctuated but the trend was downward.

Table 3 Data of variables (2014-1016)

\begin{tabular}{lllllllllllllll}
\hline & \multicolumn{1}{c}{2014} & \multicolumn{1}{c}{2015} \\
\hline NO & CODE & LEV & ROA & CR & RD & LEV & ROA & CR & RD & LEV & ROA & CR & RD \\
\hline 1 & BACA & 0.89 & 1.33 & 5 & 0.31 & 0.91 & 1.10 & 5 & 0.03 & 0.91 & 1.00 & 5 & 0.06 \\
2 & BBKP & 0.91 & 1.33 & 6 & 0.15 & 0.92 & 1.39 & 6 & 0.14 & 0.91 & 1.38 & 6 & 0.14 \\
3 & BBRI & 0.88 & 4.74 & 8 & 0.23 & 0.87 & 4.19 & 8 & 0.21 & 0.85 & 3.30 & 8 & 0.20 \\
4 & BDMN & 0.83 & 1.90 & 8 & 0.16 & 0.82 & 2.30 & 8 & 0.18 & 0.79 & 2.50 & 8 & 0.15 \\
5 & BJBR & 0.84 & 1.92 & 7 & 0.01 & 0.86 & 2.04 & 7 & 0.01 & 0.85 & 2.22 & 7 & 0.04 \\
6 & BMRI & 0.88 & 3.57 & 8 & 0.14 & 0.87 & 3.15 & 8 & 0.12 & 0.85 & 1.95 & 8 & 0.12 \\
7 & BNII & 0.90 & 0.68 & 8 & 0.12 & 0.90 & 1.01 & 8 & 0.18 & 0.86 & 1.60 & 8 & 0.11 \\
8 & BNLI & 0.91 & 1.16 & 8 & 0.11 & 0.90 & 0.20 & 8 & 0.12 & 0.88 & 4.90 & 8 & 0.09 \\
9 & BVIC & 0.86 & 0.80 & 6 & 0.14 & 0.86 & 0.65 & 6 & 0.12 & 0.85 & 0.52 & 6 & 0.11 \\
10 & NISP & 0.85 & 1.79 & 8 & 0.09 & 0.85 & 1.68 & 8 & 0.13 & 0.85 & 1.85 & 8 & 0.21 \\
11 & PNBN. & 0.87 & 2.23 & 7 & 0.11 & 0.85 & 1.31 & 7 & 0.12 & 0.84 & 1.69 & 7 & 0.12 \\
12 & PNBS & 0.83 & 1.99 & 6 & 0.19 & 0.84 & 1.14 & 6 & 0.11 & 0.86 & 0.37 & 6 & 0.13 \\
13 & SDRA & 0.76 & 2.81 & 6 & 0.10 & 0.79 & 1.94 & 6 & 0.12 & 0.81 & 1.93 & 6 & 0.13 \\
& average & 0.86 & 2.02 & 7 & 0.14 & 0.86 & 1.70 & 7 & 0.12 & 0.86 & 1.94 & 7 & 0.12 \\
\hline
\end{tabular}


Table 4 Data of Variables (2017-2019)

\begin{tabular}{rlrrrrrrrrrrrr}
\hline & \multicolumn{1}{c}{2017} & \multicolumn{1}{c}{2018} & \multicolumn{4}{c}{2019} \\
\hline NO & CODE & LEV & ROA & CR & RD & LEV & ROA & CR & RD & LEV & ROA & CR & RD \\
\hline 1 & BACA & 0.91 & 0.79 & 5 & 0.05 & 0.92 & 0.9 & 5 & 0.04 & 0.92 & 0.13 & 5 & 0.18 \\
2 & BBKP & 0.94 & 0.9 & 6 & 0.16 & 0.91 & 0.22 & 5 & 0.17 & 0.91 & 0.13 & 6 & 0.18 \\
3 & BBRI & 0.85 & 3.54 & 8 & 0.18 & 0.86 & 3.68 & 7 & 0.19 & 0.84 & 3.50 & 8 & 0.05 \\
4 & BDMN & 0.78 & 2.48 & 8 & 0.17 & 0.77 & 2.2 & 8 & 0.19 & 0.77 & 0.03 & 8 & 0.03 \\
5 & BJBR & 0.86 & 2.01 & 7 & 0.04 & 0.87 & 1.71 & 7 & 0.11 & 0.86 & 1.68 & 7 & 0.04 \\
6 & BMRI & 0.85 & 2.72 & 8 & 0.10 & 0.85 & 3.17 & 8 & 0.08 & 0.78 & 0.03 & 8 & 0.10 \\
7 & BNII & 0.86 & 1.48 & 8 & 0.12 & 0.86 & 1.74 & 8 & 0.11 & 0.82 & 0.01 & 8 & 0.20 \\
8 & BNLI & 0.85 & 0.6 & 8 & 0.14 & 0.85 & 0.8 & 8 & 0.13 & 0.85 & 0.01 & 8 & 0.04 \\
9 & BVIC & 0.85 & 0.64 & 6 & 0.10 & 0.85 & 0.33 & 6 & 0.07 & 0.85 & 0.09 & 6 & 0.03 \\
10 & NISP & 0.85 & 1.96 & 8 & 0.16 & 0.85 & 2.1 & 8 & 0.14 & 0.85 & 2.22 & 8 & 0.04 \\
11 & PNBN & 0.73 & 1.61 & 7 & 0.12 & 0.83 & 2.16 & 7 & 0.11 & 0.79 & 2.08 & 7 & 0.02 \\
12 & PNBS & 0.97 & -10.77 & 7 & 0.11 & 0.81 & 0.26 & 6 & 0.12 & 0.85 & 0.25 & 6 & 0.04 \\
13 & SDRA & 0.77 & 2.37 & 7 & 0.12 & 0.78 & 2.59 & 8 & 0.13 & 0.81 & 0.02 & 8 & 0.03 \\
& average & 0.86 & 0.79 & 7.15 & 0.12 & 0.85 & 1.68 & 7 & 0.12 & 0.84 & 0.78 & 7.15 & 0.08 \\
\hline
\end{tabular}

Classical assumption test has been employed on 78 data, however an outlier of ROA ( $-10.77 \%)$ owned by Panin Dubai Syariah Tbk Bank in 2017 has been found. Therefore, the outlier was deleted. The results of tolerance are $>0.10$, and VIF are less than 10 which exhibited that the variables are free from multicollinearity. Table 5 presents the result of the multiple linear regression test, and it shows that the adjusted R2 square is $0.128(12.8 \%)$. This indicates that contribution of DAR (X1), ROA (X2), and Credit Rating (X3) on Risk Disclosure $(\mathrm{Y})$ is $12.8 \%$, meanwhile $87.2 \%$ is supported by other variables outside the model. This study concludes that the model is not fit for predicting the factors affecting risk disclosure.

Table 5 Statistic test results

\begin{tabular}{|c|c|c|c|c|c|c|c|}
\hline \multirow[b]{2}{*}{ Model } & \multirow[b]{2}{*}{$\begin{array}{c}\text { Unstan } \\
\text { dardized B }\end{array}$} & \multirow[b]{2}{*}{$\begin{array}{l}\text { Coeff.Std } \\
\text { Error }\end{array}$} & \multirow[b]{2}{*}{$\begin{array}{l}\text { Standarzd } \\
\text { Coeff. Beta }\end{array}$} & \multirow[b]{2}{*}{$t$} & \multirow[b]{2}{*}{ Sig. } & \multicolumn{2}{|c|}{ Collinearity.stat } \\
\hline & & & & & & $\begin{array}{l}\text { Tole- } \\
\text { rance }\end{array}$ & VIF \\
\hline (constant) & -.932 & .478 & & -1.951 & .055 & & \\
\hline LLeverage (X1) & -.091 & 1.609 & -.006 & -.057 & .955 & .923 & 1.084 \\
\hline LROA (X2) & .366 & .104 & .410 & 3.516 & .001 & .843 & 1.186 \\
\hline LCredit Rating (X3) & -1.22 & .573 & -.025 & -.214 & .831 & .856 & 1.168 \\
\hline $\begin{array}{l}\text { DW } \\
\text { Adj. R Square } \\
\text { F }\end{array}$ & $\begin{array}{r}1.550 \\
.128 \\
4.729\end{array}$ & & & & & & \\
\hline
\end{tabular}

Table 5 shows that the t-test significant value of Leverage $(X 1)$ is $0.955(>0.05)$ and the Credit rating $(X 3)$ value is $0.831(>0.05)$. The results signify that $X 1$ and $X 3$ do not affect Risk Disclosure $(Y)$, and can be concluded that hypothesis $1(\mathrm{H} 1)$ and Hypothesis $3(\mathrm{H} 3)$ are rejected. Meanwhile ROA $(\mathrm{X} 2)$ has a significant value of $0.001(<0.05)$, therefore Hypothesis $2(\mathrm{H} 2)$ is accepted. This presented that ROA (X2) has positive and significant influence on Risk Disclosure $(\mathrm{Y})$. The $\mathrm{F}$ test is higher than $\mathrm{F}$ table (2.33) means that DAR, ROA and Credit rating aggregately affect Risk disclosure and supported Hypothesis 4 ( $\mathrm{H} 4)$.

\subsection{The Impact of Leverage (X1) on Risk Disclosure (Y)}

The t-test result signifies that there is no impact of leverage on risk disclosure. Therefore, Hypothesis $1(\mathrm{H} 1)$ is rejected. Bank is a financial institution with high leverage since its source of funds comes from public in the form of savings. However, high debts are risky and threatening 
companies if they fail to settle the debts along with the accrued interests. The leverage ratio can be used as a tool to predict the risks, which means that the higher the leverage rate is the higher the risks are. This indicates that bank confront higher risks owing high leverage. Jensen dan Meckling (1976) argued that companies will carefully ponder to cover their debts information.

The result corroborates Elzahar and Hussainey (2012), Linsley and Shrives (2006), Rajab and Handley-Schachler (2009) contending that no significant effect of leverage on risk disclosure. This also indicates that a high leverage rate is not inversely proportional to the comprehensive and transparent risks report since companies tend to secrete the risks and are partially disclosed them in the annual reports. This contradicts the agency theory stating that companies with a higher leverage rate provide detailed information.

The signaling theory states that companies with a high debt-to-equity ratio will send good signals and be more open to disclose their condition. Banks with high leverage will more elaborately describe their condition to ensure creditors that they can repay loans (Barako, 2007). However, this research is in opposition to the signaling theory since the banks with high leverage did not send good signals by providing less detailed information.

While, agency theory mentions that information issues between managers and stakeholders could be minimalized by disclosing transparent information. Companies with relatively small debts show a low leverage rate and low risks of being in bankruptcy (Khan, Kaleem, \& Nazir, 2012). This means that companies with low leverage ratios have greater potential to exist longer - and vice versa. However, according to Aryani and Hussainey (2017), companies do not disclose the information in detail since high leverage may give a negative image of bankruptcy. The investors are disinclined to invest for they are concerned that the majority of the assets come from the debts, resulting in increasingly high risks for the companies while not leveling off the debts. This is in line with asymmetry information where managers are reluctant to disclose information since they are fearful of the investors' negative perceptions.

\subsection{The impact of Profitability (X2) on Risk Disclosure (Y)}

Impressively, the t-test value of profitability (ROA) of 0.001 (smaller than 0.05 ) indicates there is a significant relationship between profitability (ROA) and risk disclosure. This leads to acceptance of Hypothesis $2(\mathrm{H} 2)$. This concludes that banks with higher profits transparently disclose their risks on occasion. In addition, risk reporting will be more detail when banks have a high profit, and this can fulfill stakeholders' needs. This research implicates that the result supports stakeholder theory in which companies maintain a relationship with the stakeholders by accommodating their needs and prioritizing their interests. It is consistent with agency theory that suggests a positive relationship between profitability and risk disclosure (Wachira, 2019). Furthermore, this results also in line with signaling theory which asserts that companies generates more profits tend to demonstrate openness to their stakeholders (Akhtaruddin, Hossain, Hossain, and Yao (2009), Aryani and Hussainey (2017) . It is plausible that banks with high profitability will send transparent signals to show their management performance and financial quality to their investors. Overall, there seems to be some evidence indicating that the banks elaborately report their risk based on the achievement of their profitability (ROA). This was made possible by the Bank of Indonesia Regulation number 14/14/PBI/2012 concerning transparency and publication of bank's report.

\subsection{The impact of Credit Rating (X3) on Risk Disclosure (Y)}

The t-test result of the credit rating relationship on risk disclosure shows insignificant value of 0.831 (bigger than 0.05). This confirms that there is no relationship between credit rating and risk disclosure hence this result cannot support Hypothesis $3(\mathrm{H} 3)$. It is noticeable that credit rating is not a basis for banks to be more transparent in explaining risks. This is inconsistent with Basu \& Naughton (2018), Bonsall and Miller (2017) contending that credit rating has a negative effect on risk disclosure. Moreover, Chi and Flynn (2021) asserted that low rating companies they will be more detail in reporting quality information. Therefore, this study did not support the signaling theory 
stating that companies with higher credit rating will send signals more transparent to report their risk performance. The absence of relationship between credit rating and risk disclosure is in line with Gillette et al. (2020) who asserted that investors of companies with high credit rating do not require any comprehensive information as they believe that the companies have shown good performance. In conclusion, banks which have achieved a high credit rating assumed that stakeholder already know the banks' performance consequently banks do not need to report in more transparent.

\subsection{The effect of Leverage, Profitability, and Credit Rating on Risk Disclosure}

The result of the $\mathrm{F}$ test suggests that leverage, profitability, and credit rating simultaneously influence risk disclosure as the significant value is 0.05 , and $F$ value of 4.729 is higher than the $F$ table Therefore Hypothesis 4 which states that leverage, profitability, and credit rating simultaneously influence risk disclosure is confirmed. The result exhibited that banks disclose their information aggregately based on leverage, profit, and credit rating. The result is contrary with Bagnoli and Watts (2005) who argued that the transparency of a company's risk condition report is established on the manager's intentions. This is in line with agency theory where managers will more disclose information in order to minimize agency conflict between company and stakeholders.

Regarding to adjusted $\mathrm{R}$ Square is only $12.8 \%$ means that still many factors contribute in disclosure of risks. Another factor is that banks are forced to publish their risk as their obedience to applicable regulations (Bamber \& McMeeking, 2010; Dobler, 2008). Addedly, due to corporate governance fulfillment, companies are unable to avoid reporting their performance as part of transparency (Karaibrahimoglu, 2013). To sum up, leverage, profitability and credit rating are not the only factors affect banks to report their risk in more transparent.

A final point is that there are still many factors influence banks to disclose their risk beyond our variables. For example, firm size contributes to transparent reporting because larger banks will be more complex and have higher risks than small ones (Habtoor, Ahmad, Mohamad, \& Haat, 2017). Hence banks with higher assets will assure their stakeholders that banks can manage risk better by more comprehensive in disclosing the risk (Barako, 2007). Furthermore, Elghaffar et al. (2019) underlined that the number of independent board membership and known well audit companies encourage managers to disclose banks' risks in the annual reports.

\section{Conclusion, Limitation and Recommendation}

The result of banks' risk disclosure as measured by risk keywords show that the average value over the period $2014-2019$ is only $13 \%$, even the lowest is $1 \%$ albeit the highest score is $31 \%$ this concludes that the banks tend to reluctant in disclosing their risks. Furthermore, the trend of average of risk disclosure per year was downward. The statistic test results failed to confirm the effect of Leverage and Credit rating on Risk disclosure, thus Hypothesis 1 and Hypothesis 3 are rejected. In conclusion, debt and credit rating does not matter to disclose risks in more transparent. Profitability is able to influence managers to disclose their risk more elaborately in the annual reports, accordingly Hypothesis 2 is proven.

The $\mathrm{F}$ test suggests that Leverage, ROA, and Credit Rating simultaneously affect risk disclosure. This means that the positive addition on those three variables simultaneously make significant changes to more transparent risk disclosure. This strongly supports Hypothesis 4.

The adjusted $R$ square value of $12.8 \%$ indicates that contributions of three variables consist of Leverage, ROA, and Credit Rating on risk disclosure is quite small. The rest of $87.2 \%$ is supported by other factors outside the model. These findings suggest several factors affecting bank risk disclosure beyond the factors that have been tested. In brief, since the multiple regressions cannot reveal the motivation of the three variables to increase the risk disclosure, the suggested statistic model is not fit to foretell the correlation between Leverage, ROA, and Credit Rating on Risk Disclosure.

To a new method for measuring risk disclosure in annual reports, this research makes an enormous contribution to the signaling theory, agency theory, and stakeholder theory. However, our 
work clearly has several limitations. The credit rating data of banks provided by Pefindo was very finite. Besides, the annual reports of several banks were divided into separated sections resulting in the inefficiency of converting PDF into text files. In which the conversion process produced some blank text files, consequently the corresponding samples should be removed. There were also technical issues of QSR N6.0 software instability making the text analysis process suddenly stopped. In order to minimize the paucity of QSR N6.0, it is suggested to employ the latest version of QSR N Vivo 12.2.

Started in the end of 2019, Covid-19 outbreak affected many people around the world influence economics slump and might affect banks credit rating and bank performance. Along with that, for researchers are recommended to explore with more variables to study the influence of Covid-19 pandemic on credit rating and risk disclosure, as well as comparing before and after lockdown.

\section{References}

1. Abraham, S.. \& Cox. P. (2007). Analysing the determinants of narrative risk information in UK FTSE 100 annual reports. The British Accounting Review. 39(3). 227-248.

2. Akhtaruddin, M.. Hossain. M. A., Hossain. M. \& Yao. L. (2009). Corporate governance and voluntary disclosure in corporate annual reports of Malaysian listed firms. Journal of Applied Management Accounting Research. 7(1). 1-19.

3. Aljifri, K., Alzarouni, A., Ng, C., \& Tahir, M. I. (2014). The Association between Firm Characteristics and Corporate Financial Disclosures: Evidence from UAE Companies. International Journal of Business \& Finance Research (IJBFR), 8(3), 101-123.

4. Alkurdi. A., Hussainey. K., Tahat. Y., \& Aladwan. M. (2019). The Impact of Corporate Governance on Risk Disclosure: Jordanian Evidence. Academy of Accounting and Financial Studies Journal. 23(1).

5. Al-shammari, B. (2014). Kuwait Corporate Characteristics and Level of Risk Disclosure: A Content Analysis Approach. Journal of Contemporary Issues in Business Research. 3(3). 128-153.

6. Aryani, D. N.. \& Hussainey, K. (2017). The determinants of risk disclosure in the Indonesian nonlisted banks. International Journal of Trade and Global Markets. 10(1). 58-66. doi: 10.1504/ijtgm.2017.082376

7. Bagnoli, M., \& Watts, S. G. (2005). Financial reporting and Voluntary disclosures. . Purdue University.

8. Bamber, M.. \& McMeeking, K. (2010). An examination of voluntary financial instruments disclosures in excess of mandatory requirements by UK FTSE 100 non-financial firms. Journal of Applied Accounting Research. 11(2). 133-153. doi: http://dx.doi.org/10.1108/09675421011069504

9. Bank Indonesia Regulation Number 5/8/PBI/2003 concerning Risk Management Implementation for Commercial Bank

10.Bank Indonesia Circular Letter Number 5/21/DNDP concerning Risk Management Implementation for Commercial Bank

11.Barako, D. G., Hancock, P., \& Izan, H. (2007). Determinants of voluntary disclosures in Kenyan companies annual reports. African Journal of Business Management, 1(5), 113-128.

12.Basu, R., \& Naughton, J. P. (2018). Exogenous Credit Rating Changes and the Provision of Voluntary Disclosure. Retrieved from https://www.semanticscholar.org/paper/0-ExogenousCredit-Rating-Changes-and-the-Provision-BasuNaughton/be2b8c593ae26fc4094759b360a33b951e8e305c

13.Berreta, S., \& Bozzolan. (2008). a Framework for the Analysis of Firm Risk Communication The International Journal of Accounting, 39 (3), 265-288.

14.Bonsall, S. B.. \& Miller, B. P. (2017). The impact of narrative disclosure readability on bond ratings and the cost of debt. Review of Accounting Studies. 22(2). 608-643.

15.Chi, Y. L.. \& Flynn, S. (2021). The impact of credit rating information on disclosure quality. Financial Management. doi: 10.1111/fima.12352 
16.Dobler, M. (2008). Incentives for risk reporting - A discretionary disclosure and cheap talk approach. The International Journal of Accounting. 43(2). 184.

17.Elbannan, M. A.. \& Elbannan, M. A. (2015). Economic Consequences of Bank Disclosure in the Financial Statements Before and During the Financial Crisis: Evidence From Egypt. Journal of Accounting. Auditing \& Finance. 30(2). 181-217. doi: 10.1177/0148558X14552723

18.Elghaffar, E. S. A.. Abotalib, A. M.. \& Khalil, M. A. A. M. (2019). Determining factors that affect risk disclosure level in Egyptian banks. Banks and Bank Systems. 14(1). 159-171.

19.Elshandidy, T., Fraser, I., \& Hussainey, K. (2013). Aggregated. voluntary. and mandatory risk disclosure incentives: Evidence from UK FTSE all-share companies. International Review of Financial Analysis. 30(0). 320-333. doi: http://dx.doi.org/10.1016/j.irfa.2013.07.010

20.Elzahar, H.. \& Hussainey, K. (2012). Determinants of narrative risk disclosures in UK interim reports. The Journal of Risk Finance. 13(2). 133-147.

21.Financial Services Authority regulation Number 55/POJK.03/2016 concerning Governance Implementation for Commercial Bank

22.Gillette, J. R.. Samuels, D., \& Zhou, F. S. (2020). The Effect of Credit Ratings on Disclosure: Evidence from the Recalibration of Moody's Municipal Ratings. Journal of Accounting Research. 58(3). 693-739.

23. Habtoor, O. S.. Ahmad, N., Mohamad, N. R.. \& Haat, M. H. C. (2017). Linking Corporate Risk Disclosure Practices with Firm-Specific Characteristics in Saudi Arabia. Gadjah Mada International Journal of Business. 19(3). 247-266.

24.Jensen, M. C., \& Meckling, W. H. (1976). Theory of the firm: Managerial behavior, agency costs and ownership structure. Journal of Financial Economics, 3(4), 305-360. doi: http://dx.doi.org/10.1016/0304-405X(76)90026-X

25.Junaeni, I. (2020). Analysis of Factors That Influence Decision Making Invest in Capital Markets in Millennial Generations. International Journal of Accounting \& Finance in Asia Pasific. 3(3).

26.Karaibrahimoglu, Y. Z. (2013). Is Corporate Governance A Determinant of Auditor Choice?Evidence From Turkey. Kurumsal Yönetim Denetçi Seçiminde Belirleyici midir?-Türkiye'den Bulgular.. 13(2). 273-284.

27.Khan, M. K.. Kaleem. A.. \& Nazir. M. S. (2012). Impact of Firm Capital Structure Decisions on Debt Agency Problem:Evidence for Pakistan. Journal of Basic and Applied Scientific Research.. 2(8). 7897-7905.

28.Klaus, T. (2005). The extent and determinants of narrative disclosures of risk management in annual reports of UK listed companies. Bournemouth University working paper.

29.Kravet, T., \& Muslu, V. (2013). Textual Risk Disclosures and Investors' Risk Perceptions. Review of Accounting Studies. 18(4). 1088-1122. doi: DOI 10.1007/s11142-013-9228-9

30.Linsley, P. M., \& Shrives, P. J. (2005). Transparency and the disclosure of risk information in the banking sector. Journal of Financial Regulation and Compliance. 13(3). 205-214.

31.Linsley, P. M., \& Shrives, P. J. (2006). A study of risk disclosures in the annual reports of UK. The British Accounting Review. 38. 387-404.

32.Mousa, G. A.. \& Elamir, E. A. H. (2013). Content Analysis of Corporate Risk Disclosures: The Case of Bahraini Capital Market. Global Review of Accounting and Finance. 4(1). 27-47.

33.Naser, K., Al-Khatib, K., \& Karbhari.,Y. (2002). Empirical evidence on the depth of corporate information disclosure in developing countries: The case of Jordan. International Journal of Commerce \& Management. 12(3/4). 122-155.

34.Pefindo. (2020). Rating Definitions. https://www.pefindo.com/fileman/file?file=95

35.Rahmani, N. A. B,. Maksum, A., Fachrudin, K. A., \& Silalahi, A. S. (2020). Analysis of the Effect of Profitability on General Corporate Information and Forward-looking Information and its impact on the Company's Share Prices listed on the Indonesia Stock Exchange. International Journal of Accounting \& Finance in Asia Pasific. 3(4). 32-38.

36.Rajab, B., \& Handley-Schachler, M. (2009). Corporate risk disclosure by UK firms: trends and determinants. World Review of Entrepreneurship. Management and Sustainable Development. 5(3). 224-243. doi: 10.1504/WREMSD.2009.026801 
37.Ross, S. (1979). Disclosure Regulation In Financial Markets: Implications Of Modern Finance Theory And Signaling Theory Issues In Financial Regulation: Regulation of American Business and Industry Pinpoint (pp. 177-202.).

38.Soebyakto, B. B., Mukhtaruddin, Relasari, \& Sinulingga, A. (2018). Company characteristics and risk management disclosure: empirical study of manufacturing companies listed on the Indonesia stock exchange. Problems and Perspectives in Management. 16(2).

39.Spglobal. 2020. https://www.spglobal.com/ratings/en/about/understanding-credit-ratings.

40.Wachira, M. (2019). Corporate governance and risk disclosures: An empirical study of listed companies in Kenya. African Journal of Business Management, 13(17).

41. Watts, R., \& Zimmerman, J. L. (1983). Agency Problems. auditing and theory of the firm: some evidence. Journal of Law and Economics. 12(26). 613-633. 